\title{
Performance Evaluation of a Combined Heat and Power Plant in the Niger Delta of Nigeria
}

\author{
Barikuura Gbonee, Barinyima Nkoi and John I. Sodiki
}

\begin{abstract}
This research presents the performance assessment of a combined heat and power plant operating in the Niger Delta region of Nigeria. The main focus is to evaluate the performance parameters of the gas turbine unit and the waste heat recovery generator section of the combined-heatand-power plant. Data were gathered from the manufacturer's manual, field and panel operator's log sheets and the human machine interface (HMI) monitoring screen. The standard thermodynamic equations were used to determine the appropriate parameters of the various components of the gas turbine power plant as well as that of the heat exchangers of the heat recovery steam generator (HRSG). The outcome of all analysis indicated that for every $10 \mathrm{C}$ rise in ambient temperature of the compressor air intake there is an average of $0.146 \mathrm{MW}$ drop in the gas turbine power output, a fall of about $0.176 \%$ in the thermal efficiency of the plant, a decrease of about $2.46 \%$ in the combined-cycle thermal efficiency and an increase of about $0.0323 \mathrm{Kg} / \mathrm{Kwh}$ in specific fuel consumption of the plant. In evaluating the performance of the Waste Heat Boiler (WHB), the principle of heat balance above pinch was applied to a single steam pressure HRSG exhaust gas/steam temperature profile versus exhaust heat flow. Hence, the evaporative capacity (steam flow) of the HRSG was computed from the total heat transfer in the super-heaters and evaporator tubes using heat balance above pinch. The analysis revealed that the equivalent evaporation, evaporative capacity (steam flow) and the HRSG thermal efficiency depends on the heat exchanger's heat load and its effective maintenance.
\end{abstract}

Index Terms-Combined-Heat-and-Power; Thermal Efficiency; Steam Flow; Heat Absorption; Specific Fuel Consumption.

\section{INTRODUCTION}

In the history of the human race more and more energy has been used with the discovery of new energy sources and the development of new and better conversion methods. In the first half of the twentieth century, energy sources were exploited with the primary consideration given to economics - low cost. Today, the power engineer must be concerned with the three "Es" - energy, economy and ecology [1]. Energy needs of man vary with life-style, climatic conditions, seasons and industrial progress and its demand is rising rapidly with growing population and industrialization. According to [2], one of the greatest challenges facing humanity during the twenty-first century is that of giving everyone on the planet access to safe, clean and sustainable energy supplies.

Projection of future demand of electricity is thus tied to estimates of economic growth. Therefore, the major

Published on April 6, 2019

Authors are with the Department of Mechanical Engineering, Rivers State University, Port Harcourt, Nigeria.

(e-mail: barikuuragbonee@yahoo.com; nkoi.barinyima@ust.edu.ng) technological challenge is that the energy engineer must develop systems that will produce large quantities of energy at low cost with minimal impact on the environment. In the society today, there is a high drive in most of the sectors, such as power generation, aviation, oil and gas industries, and marine propulsion towards the use of the gas turbines because of its comparative advantages over its counterpart the internal combustion engine. In the past, the base-load electric power generation was dominated by large coal and nuclear power plants [3]. Due to their high efficiencies, low capital costs, short installation times, good emission characteristics, the abundance of natural gas supplies, more and more electric utilities are using gas turbines for baseload power production as well as for peaking. The construction costs of gas-turbines are roughly half that of comparable conventional fossil-fuel steam power plants, which were the primary base-load power plants until the early 1980's. More than half of all power plants to be installed in the foreseeable future are forecast to be gas turbines or combined-gas-steam turbines.

According to [4] thermal power plants generate more than $80 \%$ of the total electricity produced in the world. Fossil fuels viz coal, fuel oil and natural gas are the energy sources. Steam is also required in many industries for process heat. To meet the dual need of power and process heat, combined-heat-and-power plants are often installed.

Gas turbines are used as stationary power plants to generate electricity as stand-alone units, or in conjunction with steam power plants. The high temperature exhaust gas from the gas turbine serves as the heat source for steam generation in either as cogeneration or combined-cycle gas turbine power plant. The bulk of supposedly waste exhaust heat associated with gas turbine operation has necessitated the need for Combined-Heat and Power (CHP) application for better fuel economy. This would render gas turbine cycles environmentally-friendly, and more economical [5].

Performance relates to the parameters of the plant. The goal for plant performance analysis is to understand accurately the operation of the various units [6]. A gas turbine operates efficiently when working under its engine design points configuration and at various component optimum performance levels [7]. Hence, several earlier researchers have shown that the efficiency of an open-cycle gas turbine plant could be increased. [8] carried out the thermodynamic appraisal of gas turbine performance in the Niger Delta. In that research, investigations were based on three prevalent conditions in the region as major factors that can modify the thermodynamics of gas turbine performance. In the course of that study, data were collated from the field measurements, service records, simulation of systems and conditions. The results revealed that a degree centigrade rise 
in ambient temperature could be responsible for a $0.83 \%$ reduction in power output, $0.17 \%$ increase in heat rate and $0.40 \%$ decrease in required air-flow rate. The study also showed that within and around the first compressor stage some water vapour condenses due to high relative humidity of the injected air resulting into conditions that facilitate metallurgical material degradation.

Similarly, fouling results in a unit reduction in compressor air flow, which yield between half and a unit reduction in the compressor isentropic efficiency. Therefore, these three climatic conditions (ambient temperature, humidity and high dust content of the air) are confirmed as critical factors which influence thermodynamic performance of gas turbine operation in the Niger Delta. The performance of a gas turbine power plant can be assessed with respect to its efficiency, power output, specific fuel consumption and as well as work ratio. Several other parameters such as compressor compression ratio, combustion inlet temperature and turbine inlet temperature are also relevant.

Thus, [9] contributed to gas turbine performance appraisal. In their research the variation of operating conditions such as compression ratio, turbine inlet and exhaust temperatures, air-to-fuel ratio, isentropic compressor and turbine efficiencies, and ambient temperature on the performance of gas turbine in terms of thermal efficiency, compressor work, power, specific fuel consumption and heat-rate were analyzed. Their results showed that the compression ratio and the isentropic efficiencies have strong effect on the thermal efficiency. Also, the thermal efficiency and power output decreased proportionally with increase of the ambient temperature and air-to-fuel ratio. However, an increase in the specific fuel consumption and heat rate is directly proportional to an increase of both ambient temperature and air-fuel ratio.

[10] contributed on the effects of ambient temperature, ambient pressure and the temperature of exhaust gases on performance of gas turbine. It was noted that an obvious drop occurs in the power output as the ambient air temperature increases. Thus, an increase in intake air ambient temperature from 15 to $30^{\circ} \mathrm{C}$ results to a $10 \%$ decrease in the power output. However, this is peculiar in the tropical climates where the ambient temperature ranges between 25 to $30^{\circ} \mathrm{C}$ throughout the year. Most gas turbines in operation today are designed based on the temperate region climatic and environmental conditions. But, the gas turbine waste heat boiler of the combined-heat-and-power plant own by the Notore Chemical Industries Limited, Onne Rivers State chosen for this study is located in the equatorial rain forest region with climatic and environmental conditions that differ greatly from those of the temperate region. Having high ambient temperatures, humidities and dust content. It is therefore, of justification that gas turbines which are designed based on the temperate region conditions but operating in the Niger Delta, will exhibit an off-design performance except necessary measures are taken.

Hence, it becomes necessary that a performance evaluation of this kind be carried out at periodic intervals as to ascertain the condition of the plant and its auxiliaries, as well as to ensure its sustainability. This performance assessment will equally enhance good maintenance culture, planning and implementations, hence reducing plant down time due to machine breakdown, maintenance and operating costs, and enhancing equipment and plant optimization.

\section{Materials AND Methods}

\section{A. Materials}

Data were collected from the manufacturer's manual, field and panel operator's log sheets and the HumanMachine Interface (HMI) system of the inspiring facility - a 25MW gas turbine combined-heat-and-power plant owned by the Notore Chemical Industries, Onne. The following units of the plant were considered:

a. Compressor Unit: mass flow rate of air, specific heat of air at constant pressure, inlet temperature, outlet temperature

b. Combustion Chamber: outlet temperature (inlet temperature of turbine) of combusted gases, fuel consumption rate, mass flow rate of exhaust gases.

c. Turbine Unit: specific heat of exhaust gases at constant pressure, outlet temperature of turbine.

d. Economizer: boiler feed water inlet temperature to economizer, economizer feed water outlet temperature, evaporative capacity of the boiler, temperature of the exhaust flue gas at inlet to economizer, specific heat of exhaust flue gases at constant pressure, Mass flow rate of the exhaust flue gases.

e. Evaporator Tubes: mass flow rate of generated steam, specific heat of steam at constant pressure, temperature of steam drum outlet.

f. Super Heater Tubes: temperature of generated steam

g. Gas Turbine Exhausts Gas Temperature Profile: exhaust gas inlet temperature to boiler, gas exit temperature from evaporator.

These parameters are collated and shown in Table I, II

\section{B. Methods}

The performance of the gas turbine combined heat and power plant was evaluated with respect to its compressor work, turbine work, gas turbine power output (net work), work ratio, thermal efficiency, HRSG evaporation capacity (steam flow), equivalent evaporation, heat exchanger's heat load, and overall thermal efficiency of the HRSG.

Application of the one-dimensional steady flow energy equation and heat balance to the various components of the open cycle gas turbine as well as the heat exchangers of the HRSG gave rise to the relevant thermodynamic equations for the evaluation of the plant performance parameters.

The results obtained are shown using Microsoft Excel micro excel graphics.

i. Gas Turbine Cycle

The open cycle gas turbine consists of the compressor unit, combustion chamber and turbine unit as shown in Fig. 1. 


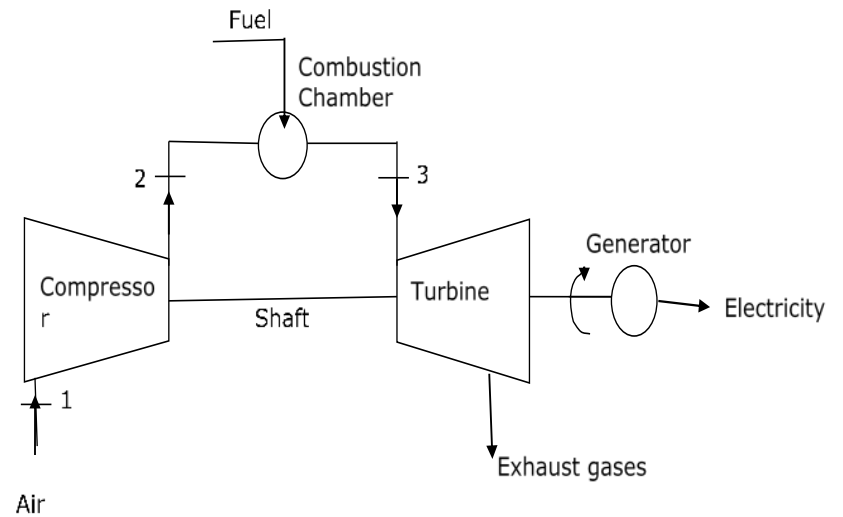

Fig. 1. Schematic of open cycle gas turbine.

ii. Thermodynamic processes of the open cycle gas turbine power plant

Fig. 2 shows the thermodynamics processes of the open cycle gas turbine power plant on a T-S diagram.

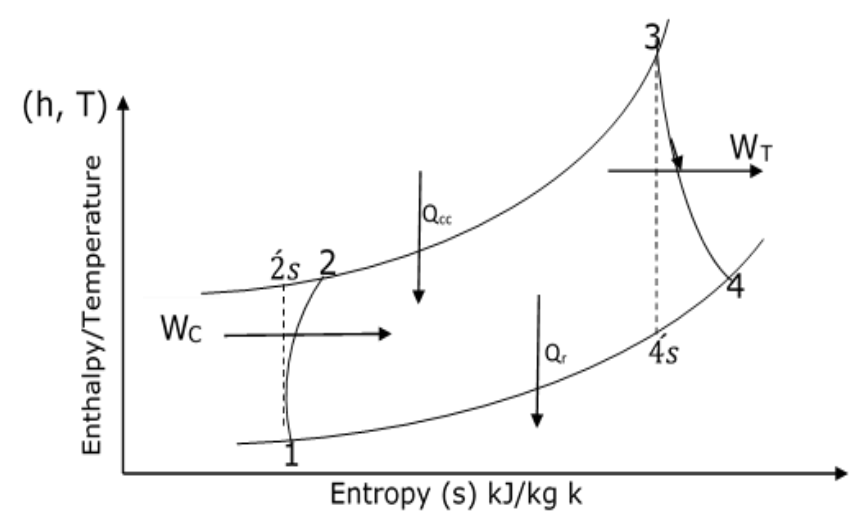

Fig. 2. Open Cycle on a T-S diagram.

Fig. 2: Open Cycle on a T-S diagram

Process 1-2's represents: Ideal isentropic compression

Process 1-2 represents: Irreversible adiabatic compression

Process 2-3 represents: Constant pressure heat addition in the combustion chamber.

Process 3-4's represents: Ideal isentropic expansion

Process 3-4 represents: Irreversible adiabatic expansion

Process 4-1 represents: Constant pressure rejection of heat.

$\mathrm{Q}-\mathrm{W}=\dot{m}\left[\left(h_{2}-h_{1}\right)+1 / 2\left(q_{2}^{2}-q_{1}^{2}\right)+g\left(Z_{2}-\mathrm{Z}_{1}\right)\right]$

where

$\mathrm{Q}=$ Heat addition; $\mathrm{W}=$ work done

$\dot{m}=$ mass flow rate.

$\left(\mathrm{h}_{2}-\mathrm{h}_{1}\right)=$ change in enthalpy

$1 / 2\left(q_{2}^{2}-q_{1}^{2}\right)=$ change in kinetic energy

$\mathrm{g}\left(Z_{2}-Z_{1}\right)=$ change in potential energy

For perfect gases

$\mathrm{dh}=\mathrm{C}_{\mathrm{p}} \mathrm{dT}$ where

$\mathrm{dh}=$ change in enthalpy

$\mathrm{C}_{\mathrm{p}}=$ specific heat

$\mathrm{dT}=$ change in temperature (Royers \& Mayhew, 2004).

Applying equations 1 and 2:

Compressor work is given by equation (3)

$\mathrm{W}_{\mathrm{c}}=\dot{m}_{\mathrm{a}} C_{a}\left(\mathrm{~T}_{2}-T_{1}\right)$

where

$\mathrm{W}_{\mathrm{c}}=$ compressor work, $C p=$ specific heat of air at constant pressure

$\dot{m}_{\mathrm{a}}=$ mass flow rate of air

$\mathrm{T}_{2}=$ outlet temperature of air

$\mathrm{T}_{1}=$ inlet temperature of air

Combustion heat added is given by equation (4)

$\mathrm{Q}_{\mathrm{cc}}=\dot{m}_{a} \dot{C}_{p_{a}}\left(T_{3}-T_{2}\right)$

where $\mathrm{Q}_{\mathrm{cc}}=$ heat supplied

$C_{p_{a}}=$ specific heat of air at constant pressure

$\dot{m}_{a}=$ air mass flow rate

$\mathrm{T}_{3}=$ outlet temperature of combusted exhaust gases

Turbine work is given by

$\mathrm{W}_{\mathrm{T}}=\dot{m}_{a} \dot{C}_{p_{a}}\left(T_{4}-T_{3}\right)$

where $\mathrm{W}_{\mathrm{T}}=$ turbine work output

$\mathrm{T}_{4}=$ outlet temperature of turbine

Heat Rejected is given by

$\mathrm{Q}_{\mathrm{r}}=\dot{m}_{a} \dot{C}_{p_{a}}\left(T_{4}-T_{1}\right)$

where $\mathrm{Q}_{\mathrm{r}}=$ heat rejected

Net power output is given by

$\mathrm{W}_{\text {net }}=\mathrm{W}_{\mathrm{T}}-\mathrm{W}_{\mathrm{c}}$

Gas turbine cycle thermal efficiency is given by

$\eta_{t h_{T}}=\frac{\text { Net } \text { work output }}{\text { Heat Supplied or heat input }}=\frac{W_{N e t}}{Q_{c c}}$

Work ratio is given by

$\mathrm{r}_{\mathrm{w}}=\frac{\text { Net } \text { work output }}{\text { Turbine } \text { work output }}=\frac{W_{\text {Net }}}{W_{T}}$

iii. Heat Recovery Steam Generator (HRSG) Unit Performance Analysis

Fig. 3. Illustrates a single steam pressure HRSG exhaust gas/steam temperature profile versus heat loads.

From Figure 3

The path $v-y-x-n$ indicates gas turbine exhaust gas temperature profile.

The path a-b-c-d-e indicates steam temperature profile.

Then applying Equation 1 (1-D Steady flow energy 
equation):

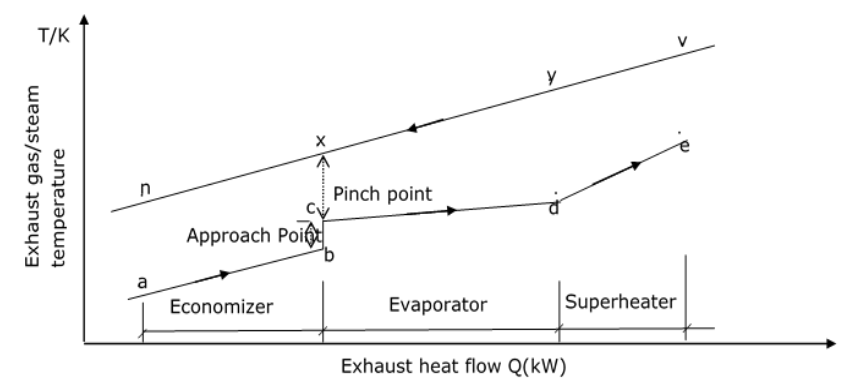

Fig. 3. Single steam pressure HRSG exhaust gas/steam temperature profile versus heat loads.

Heat exchangers heat load (heat absorbed in the various exchangers sections) are:

Economizer; $\mathrm{Q}_{\mathrm{eco}}=\dot{m}_{w}\left(\mathrm{~h}_{\mathrm{c}}-\mathrm{h}_{\mathrm{a}}\right)$

Evaporator Tubes: $\mathrm{Q}_{\mathrm{eva}}=\dot{m}_{s}\left(\mathrm{~h}_{\mathrm{d}}-\mathrm{h}_{\mathrm{c}}\right)$

Super heater Tubes: $\mathrm{Q}_{\mathrm{sh}}=\dot{m}_{\mathrm{s}}\left(\mathrm{h}_{\mathrm{e}}-\mathrm{h}_{\mathrm{d}}\right)$

Total HRSG Load, $\mathrm{Q}_{\mathrm{HRSG}}=\mathrm{Q}_{\mathrm{eco}}+\mathrm{Q}_{\mathrm{eva}}+\mathrm{Q}_{\text {sh }}$

where

$\mathrm{Q}_{\text {eco }}=$ economizer heat load

$\dot{m}_{w} \quad=$ feed water mass flow rate

$\dot{m}_{s} \quad=$ steam flow rate

$\mathrm{h}_{\mathrm{c}} \quad=$ specific enthalpy of saturated water at evaporator inlet evaporator inlet

$\mathrm{h}_{\mathrm{a}} \quad=$ specific enthalpy of feed water at economizer inlet temperature

$\mathrm{Q}_{\mathrm{eva}} \quad=$ evaporator heat load

$\mathrm{h}_{\mathrm{d}} \quad=$ specific enthalpy of saturated steam at evaporator

outlet

$\mathrm{Q}_{\mathrm{SH}} \quad=$ super heater heat load

$\mathrm{h}_{\mathrm{e}} \quad=$ specific enthalpy of superheated steam

(Nag, 2013).

where

Qeco = economizer heat load

$\mathrm{m}_{\mathrm{w}} \quad=$ feed water mass flow rate

$\mathrm{m}_{\mathrm{s}} \quad=$ steam flow rate

$\mathrm{h}_{\mathrm{c}} \quad=$ specific enthalpy of saturated water at evaporator inlet evaporator inlet

$\mathrm{h}_{\mathrm{a}} \quad=$ specific enthalpy of feed water at economizer inlet temperature

$\mathrm{Q}_{\mathrm{eva}}=$ evaporator heat load

hd $=$ specific enthalpy of saturated steam at evaporator

outlet

$\mathrm{Q}_{\mathrm{sh}} \quad=$ super heater heat load

he $\quad=$ specific enthalpy of superheated steam

(Nag, 2013).

Steam Flow $\left(\mathrm{m}_{\mathrm{s}}\right)$ (Actual mass of steam generated per unit mass of fuel burnt):

From principle of heat balance and Fig. 3 total heat transfer in the superheater and evaporator tubes $=Q_{\text {eva }}+Q_{\text {sh }}$ Thus,

$\mathrm{Q}_{\mathrm{vx}}=\mathrm{Q}_{\mathrm{eva}}+\mathrm{Q}_{\mathrm{sh}}=\mathrm{Q}_{\mathrm{dc}}+\mathrm{Q}_{\mathrm{ed}}$

$$
Q_{v x}=M_{e g} C p_{e g} f_{1}\left(T_{v}-T_{x}\right)
$$

Then, substituting equations $11,12 \& 15$ into equation 14 , Implying that;

$$
\begin{aligned}
& \mathrm{m}_{\mathrm{a}} \mathrm{Cp}_{\mathrm{a}} \mathrm{f}_{1}\left(\mathrm{~T}_{\mathrm{v}}-\mathrm{T}_{\mathrm{x}}\right)=\dot{m}_{s}\left[\left(h_{e}-h_{d}\right)+f_{2}\left(h_{d}-h_{c}\right)\right] \\
& \dot{m}_{s}=\frac{\boldsymbol{m}_{\boldsymbol{a}} \boldsymbol{C} \boldsymbol{p}_{\boldsymbol{a}} \boldsymbol{f}_{\mathbf{1}}\left(\boldsymbol{T}_{\boldsymbol{v}}-\boldsymbol{T}_{\boldsymbol{x}}\right)}{\left(\boldsymbol{h}_{\boldsymbol{e}}-\boldsymbol{h}_{\boldsymbol{d}}\right)+\boldsymbol{f}_{\mathbf{2}}\left(\boldsymbol{h}_{\boldsymbol{d}}-\boldsymbol{h}_{\boldsymbol{c}}\right)}
\end{aligned}
$$

\section{where}

$\mathrm{Q}_{\mathrm{vx}} \quad=$ heat supplied by exhaust gas

$\mathrm{Q}_{\mathrm{dc}} \quad=$ heat absorbed by evaporator tubes

$\mathrm{Q}_{\mathrm{ed}} \quad$ = gas absorbed by super heaters

$\mathrm{T}_{\mathrm{v}} \quad$ = gas Exhaust temperature to boiler

$\mathrm{T}_{\mathrm{x}} \quad$ = gas temperature exit of evaporator

$\mathrm{f}_{1} \quad=$ heat loss factor

$\mathrm{f}_{2} \quad=$ blow down factor

[5].

Equivalent Evaporation (the mass of water evaporated to produce steam over a period of time and at a particular set of operating conditions)

$$
\mathrm{Eva}_{\mathrm{eq}}=\quad \mathrm{m}_{\mathrm{s}} \frac{\left(H_{s}-H_{f w}\right)}{H_{f g}}
$$

where

$\mathrm{E}_{\mathrm{vaeq}}=$ equivalent evaporation

$\mathrm{m}_{\mathrm{s}} \quad=$ evaporation capacity (Actual mass of steam generated per unit mass of fuel burnt)

$\mathrm{H}_{\mathrm{s}}=$ specific enthalpy of steam under operating conditions

$\mathrm{H}_{\mathrm{fw}} \quad=$ specific Enthalpy of feed water.

$\mathrm{H}_{\mathrm{fg}} \quad=$ latent heat of dry saturated steam (feed water inlet temperature to economizer) [11].

HRSG thermal efficiency $\left(\eta_{t h}\right)$

The thermal efficiency of a boiler could be assessed on the relationship between the energy to the steam (heat output) and the energy from the burning fuel (heat input).

That is,

$$
\eta_{\text {th }}=\frac{\text { Energy to steam }}{\text { Energy from fuel }}
$$

In the case of the waste heat boiler (WHB), energy from the fuel is a combination of the heat supplied by the gas turbine exhaust gases as well as that of the supplementary fuel firing input to the boiler.

Therefore, the boiler thermal efficiency could be calculated as

$\eta_{t h H R S G}=\frac{Q_{H R S G}}{Q e g+Q s f}$

And that;

$\mathrm{Q}_{\mathrm{sf}}=\mathrm{K} \mathrm{Cv_{ \textrm {f } }}$

$\mathrm{Q}_{\mathrm{eg}}=\mathrm{M}_{\mathrm{eg}} \mathrm{Cp}_{\mathrm{eg}} \mathrm{T}_{\mathrm{v}}$

But,

where 


$\begin{array}{ll}\eta_{t h H R S G} & =\text { boiler thermal efficiency } \\ Q_{H R S G} & =\text { energy to steam (Total Heat load of } \\ \text { HRSG) } & \\ \text { Qeg } & =\text { energy of gas turbine exhaust gasses } \\ \text { Qsf } & =\text { energy of supplementary fuel firing } \\ \text { input } & =\text { fuel consumption } \\ \mathrm{K} & =\text { exhaust gas temperature at boiler inlet } \\ \text { Tv } & \end{array}$
[12].

\section{RESULTS AND DisCUSSION}

\section{A. Thermodynamic performance Evaluation of the Components of the Gas Turbine Combined-Heat-and- Power Plant}

With reference to the equations deduced in Section 2.0 of this work, collected data and parameters of the inspiring facility - Notore gas turbine combined-heat-and-power plant as depicted in Table 1 and Appendix 1, the thermodynamic performance parameter behaviour of the various engine components of the gas turbine unit as well as that of the heat exchangers of the waste heat boiler (Heat Recovery Steam Generator) section were evaluated.

TABLE I: GAS TURBINE - OPERATION DATA (SOURCE: NOTORE UTILITIES CONTROL ROOM/ HMI SYSTEM)

\begin{tabular}{lllll}
\hline \hline S/N & $\begin{array}{l}\text { Ambient } \\
\text { Tempt } \\
\left(\mathrm{T}_{1}\right)^{\circ} \mathrm{C}\end{array}$ & $\begin{array}{l}\text { Compressor } \\
\text { Exit } \\
\text { Air Inlet }\end{array}$ & $\begin{array}{l}\text { Turbine Inlet } \\
\text { Tempt }\left(\mathrm{T}_{2}\right)^{\circ} \mathrm{C}\end{array}$ & $\begin{array}{l}\text { Turbine Exit } \\
\left(\mathrm{T}_{3}\right)^{\circ} \mathrm{C}\end{array}$ \\
\hline 25 & 325 & & $\begin{array}{c}\text { Tempt. } \\
\left(\mathrm{T}_{4}\right)^{\circ} \mathrm{C}\end{array}$ \\
26 & 326.8 & 824.8 & 383 \\
27 & 328.2 & 825.6 & 384 \\
28 & 329.7 & 826.3 & 384.9 \\
29 & 331.3 & 827 & 385.8 \\
30 & 333.7 & 828 & 387.3 \\
31 & 335 & 829 & 388.4 \\
32 & 336.4 & 829.3 & 390.3 \\
33 & 338 & 829.7 & 392 \\
\hline \hline
\end{tabular}

Gas Turbine Performance Evaluation

With the aid of equations $1,2,3,4,5,6,7$ and 8 and the appropriate parameters from Table 1 the compressor work, turbine work, net work, work ratio, heat addition/rejection, thermal efficiency and specific fuel consumption rate of the gas turbine-heat-and-power plant are evaluated at the various operating ambient temperatures ranging between $25^{\circ} \mathrm{C}$ to $33^{\circ} \mathrm{C}$. These values are tabulated in Table II.

TABLE II: GAS TURBINE PARAMETERS EVALUATION TABLE

TABLE III: HRSG EXHAUST GAS/STEAM TEMPERATURE READINGS

\begin{tabular}{|c|c|c|c|c|c|c|}
\hline $\mathrm{S} / \mathrm{NO}$ & $\begin{array}{l}\text { Ambient } \\
\text { Tempt }\left(\mathrm{T}_{1}\right)^{\mathrm{O}} \mathrm{C}\end{array}$ & $\begin{array}{l}\text { Exhaust Gas } \\
\text { Tempt. } \mathrm{T}_{\mathrm{v}}\left({ }^{\circ} \mathrm{C}\right) \\
\end{array}$ & $\begin{array}{l}\text { Evaporator Gas exit } \\
\text { Tempt } \mathrm{T}_{\mathrm{x}}\left({ }^{\circ} \mathrm{C}\right)\end{array}$ & $\begin{array}{l}\text { Saturated } \mathrm{H}_{2} \mathrm{O} \text { inlet Tempt. } \\
\text { To Evaporator } \mathrm{T}_{\mathrm{c}}\left({ }^{\circ} \mathrm{C}\right)\end{array}$ & $\begin{array}{l}\text { Saturated steam outlet } \\
\text { Tempt. To evaporator } \mathrm{T}_{\mathrm{d}}\left({ }^{\circ} \mathrm{C}\right)\end{array}$ & $\begin{array}{l}\text { Super-heated steam } \\
\text { exit Tempt. } \mathrm{T}_{\mathrm{e}}\left({ }^{\circ} \mathrm{C}\right)\end{array}$ \\
\hline & 25 & 508 & 238 & 223 & 360 & 415 \\
\hline & 26 & 509 & 242 & 227 & 361 & 421 \\
\hline & 27 & 510 & 245 & 230 & 362 & 425 \\
\hline & 28 & 510 & 247 & 232 & 363 & 429 \\
\hline & 29 & 511 & 250 & 235 & 365 & 434 \\
\hline & 30 & 513 & 253.5 & 238.5 & 367 & 437 \\
\hline & 31 & 514 & 255 & 240 & 369 & 441 \\
\hline & 32 & 516 & 257 & 242 & 372 & 445 \\
\hline & 33 & 518 & 260 & 245 & 374 & 450 \\
\hline
\end{tabular}

TABLE IV: HRSG PERFORMANCE PARAMETER EVALUATION

\begin{tabular}{|c|c|c|c|c|c|c|c|c|c|}
\hline $\mathrm{S} / \mathrm{N}$ & $\begin{array}{l}\text { Ambient } \\
\text { Tempt } \\
\left(\mathrm{T}_{1}\right)^{\circ} \mathrm{C}\end{array}$ & $\begin{array}{l}\text { Steam } \\
\text { flow } \\
(\mathrm{ms}) \\
\mathrm{kg} / \mathrm{s} \\
\end{array}$ & $\begin{array}{l}\text { Equivalent } \\
\text { Evaporation } \\
\text { Evaeg }(\mathrm{kg} / \mathrm{s})\end{array}$ & $\begin{array}{l}\text { Economizer } \\
\text { heat lead } Q_{\text {eco }} \\
(\mathrm{KJ} / \mathrm{s})\end{array}$ & $\begin{array}{l}\text { Evaporator } \\
\text { Heat Load } \\
\text { QEva }_{(\mathrm{KJ} / \mathrm{s})}\end{array}$ & $\begin{array}{l}\text { Super-heater } \\
\text { heat load } \\
\mathrm{Q}_{\mathrm{SH}}(\mathrm{KJ} / \mathrm{s})\end{array}$ & $\begin{array}{l}\text { Total HRSG } \\
\text { heat load } \\
\text { Q }_{\text {HRSG }}(\mathrm{KJ} / \mathrm{s})\end{array}$ & $\begin{array}{l}\text { HRSG } \\
\text { thermal } \\
\text { efficiency } \%\end{array}$ & $\begin{array}{l}\text { Combined } \\
\text { Cycle thermal } \\
\text { efficiency } \\
\eta_{\text {thCHP }} \%\end{array}$ \\
\hline & 25 & 44.42 & 55.61 & 12214.10 & 67648.55 & 34287.80 & 114150.45 & 85.39 & 109.28 \\
\hline & 26 & 42.67 & 53.68 & 12682.29 & 63724.66 & 33960.68 & 110367.58 & 82.48 & 106.22 \\
\hline & 27 & 41.35 & 52.19 & 13032.7 & 60697.67 & 33769.72 & 107500.09 & 80.26 & 103.88 \\
\hline & 28 & 40.38 & 51.13 & 13252.78 & 58435.51 & 33829.96 & 105518.27 & 78.46 & 102.09 \\
\hline & 29 & 38.12 & 48.47 & 13590.16 & 53634.84 & 33379.40 & 100604.40 & 74.70 & 98.03 \\
\hline & 30 & 36.44 & 46.44 & 14000.07 & 49554.03 & 33270.08 & 96824.18 & 71.81 & 94.87 \\
\hline & 31 & 34.69 & 44.36 & 14179.33 & 45630.19 & 33284.71 & 92824.23 & 68.72 & 91.43 \\
\hline & 32 & 32.23 & 41.35 & 14417.86 & 39894.29 & 33407.04 & 87719.19 & 64.83 & 87.22 \\
\hline & 33 & 27.49 & 35.41 & 14775.39 & 28959.62 & 33478.42 & 77213.43 & 57.03 & 79.30 \\
\hline
\end{tabular}


Off- Design Behaviour of the Gas Turbine Combined-Heatand-Power Plant

Table I, II, III and IV shows the operating and evaluated data of the thermodynamic parameters of the gas turbine Combined-Heat-and-Power plant.

Thus, the clarity of the effects of these Parameters on the technical performance assessment of the Gas Turbine power plant can be simplified via graphical presentations as shown in Fig. 4 to 9.

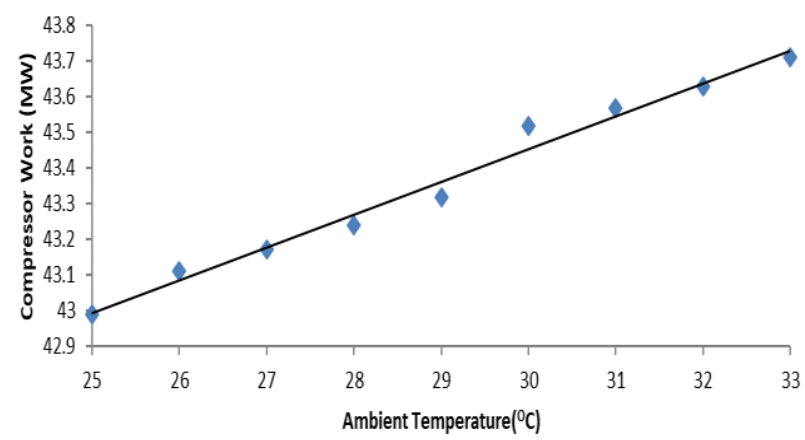

Fig. 4. Effect of Ambient Temperature on Compressor work.

From Fig. 4, it is observed that as operating ambient temperature of the intake air increases, compressor work reduces. This means that the compressor efficiency of the machine is inversely proportional to increase in ambient temperature.

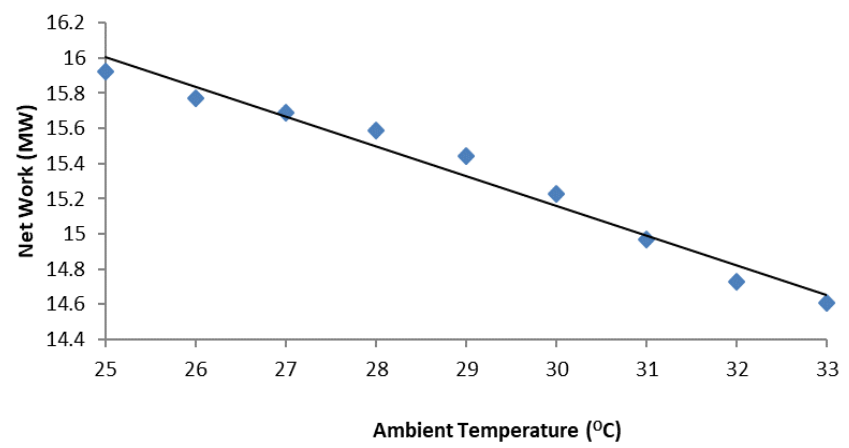

Fig. 5. Effect of Ambient Temperature on Gas Turbine Net Power output.

From Fig. 5, the gas turbine power output is inversely proportional to ambient temperature. That is, as the ambient temperature increases, the compressor work required to compress the hot air reduces. Since most of the produced work is being utilized by the compressor unit it therefore means that the shaft power available for power generation is reduced.

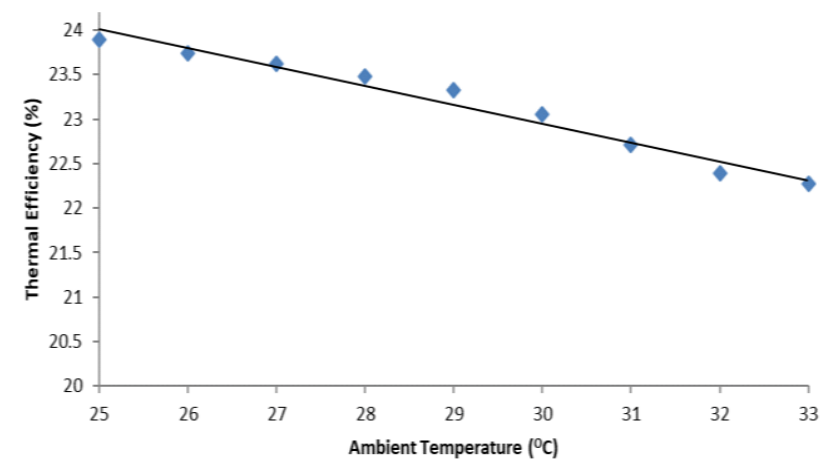

Fig. 6. Effect of Ambient Temperature on the Gas Turbine Thermal Efficiency.
From Fig. 6 and Table II it would be deduced that as ambient temperature increases then, the thermal efficiency of the gas turbine reduces. This is because the useful work drops as a result of the fraction of work required to compress the hot air.

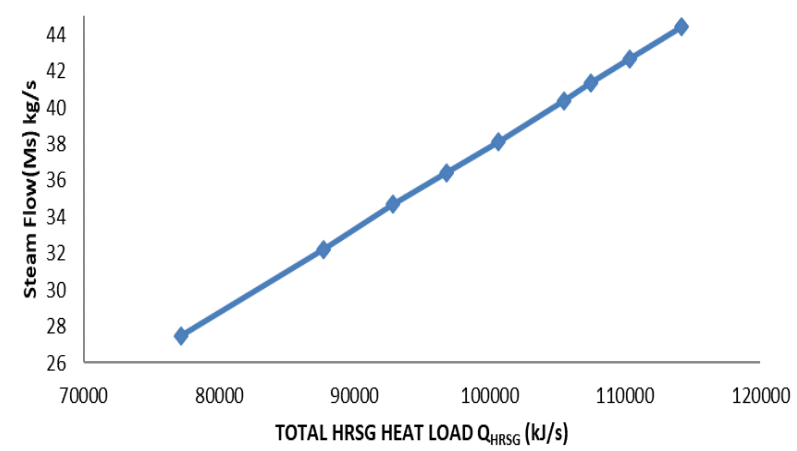

Fig. 7. Effect of Total HRSG Heat Load on Equivalent Evaporation of the HRSG.

Fig. 7 illustrates the behaviour total heat absorption rate of the HRSG to the equivalent evaporation. Thus, as the heat absorption rate of the HRSG increase its equivalent evaporation also increases. It means that the quantity of water that gets evaporated in the HRSG is directly proportional to the heat transfer rate of the HRSG heat exchanger tubes.

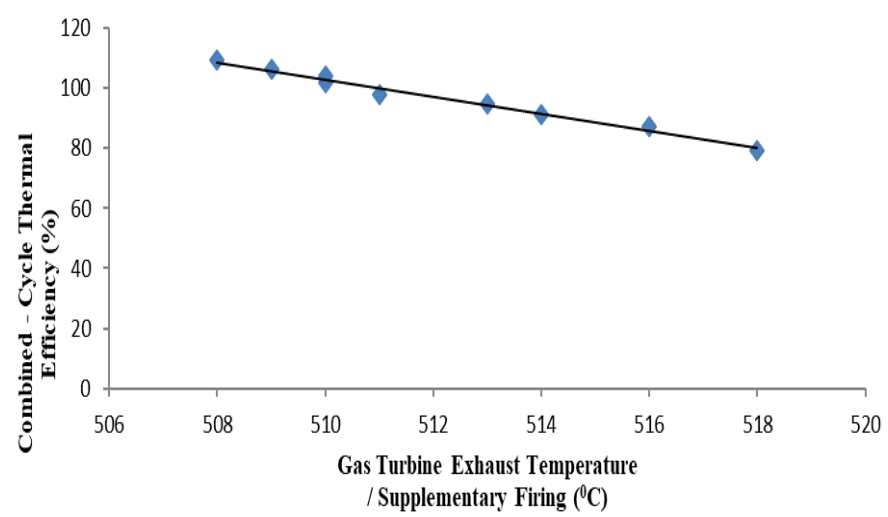

Fig. 8. Effect of Gas Turbine Exhaust Temperature/Supplementary Firing on the Combined-Cycle Thermal Efficiency.

From Fig. 8 it is noted that as the gas turbine exhaust temperature increase, then the combined-cycle thermal efficiency decreases. Hence, from the analysis it is deduced that a $1^{\circ} \mathrm{C}$ rise in the turbine exhaust temperature results to an average of about $2.46 \%$ fall in the combined-cycle thermal efficiency.

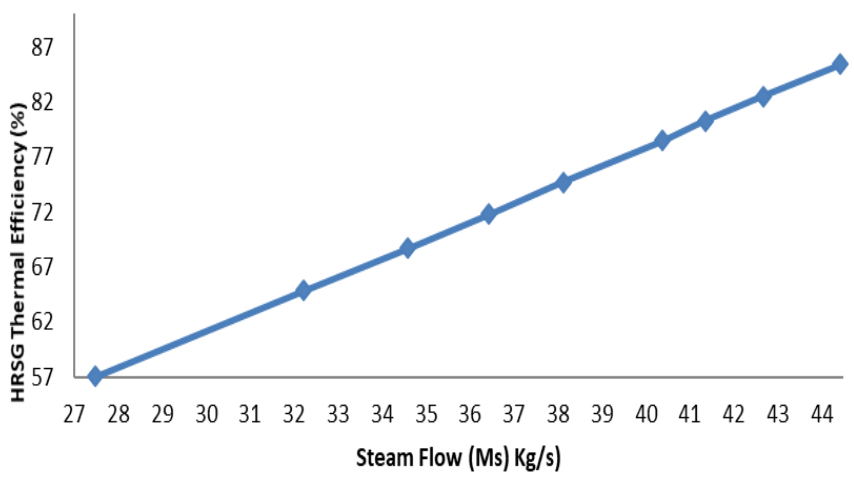

Fig. 9. Effect of (steam flow rate) on thermal efficiency of the HRSG. 
As the mass of steam generated per unit mass of fuel burnt increases the thermal efficiency of the HRSG also increases that means the energy input of the fuel is directly proportional to energy gained by the steam generated.

\section{CONCLUSION}

The performance of a Gas Turbine Combine-Heat-and power plant inspired by the Notore gas turbine-combinedheat-and-power plant facility has been evaluated via the application of some relevant thermodynamic equations. From the fore-going analysis of the technical performance of the gas turbine power plant, it is a possible justification to say that the effectiveness of the operation of a gas turbine power plant depends on several factors including its operating climatic and environmental conditions. These should be duly considered during the preliminary design stage of the gas turbine power plant before its installation in any choice of geographical location. This peculiar condition accounted for by this research is the high ambient temperature of the Niger Delta area of Nigeria where the Notore gas turbine power plant is located. It ranges between $25^{\circ} \mathrm{C}$ to $33^{\circ} \mathrm{C}$ as against the designed ambient temperature of about $15^{\circ} \mathrm{C}$. This high ambient temperature has a negative effect on the thermodynamic processes as well as the components in which these processes do occur. From the analysis it is observed that an increase in the ambient temperature brings about a drop in the gas turbine net power output as well as a fall in the thermal efficiency of the gas turbine power plant and also reduces the combined cycle thermal efficiency of the plant. This is because the useful work drops as a result of a fraction of compression work required to compress the hot air. From Table IV and Fig. 7, it is obvious that the heat absorption rate of the heat exchanger tubes (economizer, evaporator and super heater tubes) is a determinant for the evaporation capacity of the HRSG. This implies that the higher the heat transfer rate the more amount of water evaporated from water at the HRSG operating conditions. Hence, as the heat load of the HRSG increases the equivalent evaporation of the HRSG also increases. Also, this increase in the HRSG heat load leads to a corresponding increase in the actual mass of steam generated per unit mass of fuel burnt which result to increase in the thermal efficiency of the HRSG system. Therefore, it may be pertinent to state that the efficiency of a HRSG depends greatly on the nature of materials of make for the heat exchanger tubes and the maintainability of the boiler tubes. This paper shows that exhaust gases at a temperature as high as $792 \mathrm{k}\left(519^{\circ} \mathrm{C}\right)$ leaves the Notore gas turbine power plant exhaust port and are utilized by the HRSG unit (WHB) to produce useful steam. This supposed to be emitted as a source of pollution to its environment. This work indicates an effective technical thermodynamic performance evaluation of the Notore gas turbine Combined-Heat-and-Power plant. Hence, the objective of this research has been achieved. This paper contributes to the understanding that the effectiveness of a Heat Recovery Steam Generator in terms of its evaporation capacity, equivalent evaporation and overall thermal efficiency is a function of the heat exchangers heat absorption capacity. As a measure to mitigate the problem of high ambient air - intake temperature to the compressor unit, an absorption chiller can be installed at the compressor inlet port to reduce the high ambient temperature. It should be easily implemented and its installation should not alter the turbine set configuration. During shut down and maintenance periods substandard materials, accessories and spare parts should not be used as to replace or repair damaged parts in the HRSG heat exchanger's tubes or components in the entire plant assembly. This is because such spare parts may affect the heat absorption capacity of the HRSG and may lead to inefficiency of the HRSG as well as impair the performance of the whole system. Further research could be carried out on the exergy-based performance analysis to improve on the performance of the Notore gas turbine power plant.

\section{ACKNOWLEDGMENT}

We sincerely appreciate the shift superintendent $\mathrm{Mr}$. Steve Ochimba Ngoke of the Urea Plant, Notore Chemicals Industries Ltd. Onne and other Notore staff for their advice and contributions.

\section{REFERENCES}

[1] Culp, A. W. (JR), (1979). Principles of Energy Conversion, McGrawHill.

[2] Yadav, R. (2009). Steam \& Gas Turbine and Power Plant Engineering Central Publishing House, Allahabab.

[3] Cengel, Y. A. Turner, R. H \& Cimbala, J. M (2008). Fundamentals of Thermal-Fluid Science. Published by McGraw-Hill Companies, Inc. 1221 Avenue of the Americas, New York, NY 10020.

[4] Nag, P. k. (2013). Power Plant Engineering, 3rd Edition, New Delhi; India, Tata McGraw-Hill Education Private Limited.C. Y. Lin, M Wu, J. A. Bloom, I. J. Cox, and M. Miller, "Rotation, scale, and translation resilient public watermarking for images," IEEE Trans. Image Process., vol. 10, no. 5, pp. 767-782, May 2001.

[5] Nkoi, B \& Lebele-Alawa, B. T. (2015). Comparative Assessment of combined-Heat-and-Power performance of Small-Scale AeroDerivative Gas Turbine Cycles. Journal of Power and Energy Engineering, 3.20-32. http://dx.doi.org/10.4236 /ipee.2015.39002.

[6] Perry, R. H, \& Green, D. (1998). Chemical Engineers Hand Book. U.S.A, $7^{\text {th }}$ ed, McGraw-Hill Book Company.

[7] Walsh, P. P, \& Fetcher, P. (2010). Gas turbine performance, 2nd Edition, Blackwell Publishing. Wiley India PVT. Ltd.

[8] Hart, H. I. (1998). Thermodynamic Appraisal of Niger Delta Gas Turbine Performance. PhD's Thesis, Mechanical Engineering. University of Nigeria, Nsukka, Nigeria.

[9] Rahman, M. M, Thamir, K. I, \& Ahmed, N. A. (2011) Thermodynamic Performance Analysis of Gas Turbine Power Plant www.academic journals. Org/article/article 1380722812-rahman \%20 et $\% 20$ al. pdf.

[10] Boonasa, S., Namprakai, P. \& Muangnapoh, T. (2006). Performance Improvement of the combined cycle power plant by intake air cooling using an absorption chiller. Energy, 31(12).

[11] Chattopadhyay, P. (2001). Boiler Operation Engineering Question and Answers. 2nd Edition, McGraw-Hill Companies, Inc. U.S.A.

[12] Mitsubishi, (1985). National Fertilizer Company of Nigeria Ltd Nitrogenous Fertilizer Project, Rivers State. Operation and Maintenance Manual. Model: MW -251, serial No. T- 206. Customer job No. 6348-50, Vol. M-1. 